\title{
ANALISIS EFEKTIVITAS DAN KONTRIBUSI PENERIMAAN PAJAK REKLAME, PAJAK BUMI DAN BANGUNAN TERHADAP PENDAPATAN ASLI DAERAH KABUPATEN SIAU TAGULANDANG BIARO
}

\author{
Marce Takasili Hebimisa ${ }^{1}$, Jullie J. Sondakh ${ }^{2}$, Anneke Wangkar $^{3}$ \\ 1,2,3 Jurusan Akuntansi, Fakultas Ekonomi dan Bisnis, Universitas Sam Ratulangi, Jl. Kampus Bahu, Manado, \\ 95115, Indonesia
}

E-mail : Wiwinhebimisa030396@gmail.com

\begin{abstract}
The Original Revenue is the receipts from the levy of local taxes, levies, wealth management,wealth management area separated, and other income. Income areas in the implementation of regional autonomy is expected to contribute in financing the public interest and the interests of individual communities. Advertisement tax, tax on land and buildings included in local taxes. The purpose of this study is to determine the level of effectiveness and the contribution of advertisement tax, land and building tax to the local revenue District of Siau Tagulandang Biaro. The method of analysis used is quantitative descriptive method, to analyze data the realization of advertisement tax, tax on land and buildings from the years 2014-2016.The results of the research the overall level of effectiveness of the advertisement tax revenue, land and building tax in the year 2014-2016 this is very effective. The contribution of advertisement tax, land and building tax in the year of 2014-2016 rated not optimal and the criteria included in the contribution is very less. Finance agency Kabupaten Siau Tagulandang Biaro preferably improve the function of the control in the collection of advertisement tax, tax on land and buildings to increase the tax contribution to Local Revenue Kabupaten Siau Tagulandang Biaro.
\end{abstract}

Keywords : local Revenue, local taxes, effectiveness, contribution

\section{PENDAHULUAN}

Negara Republik Indonesia adalah negara hukum berdasarkan Pancasila dan UndangUndang Dasar 1945 yang menjunjung tinggi hak dan kewajiban setiap masyarakat. Oleh karena itu negara menempatkan perpajakan sebagai perwujudan salah satu kewajiban kenegaraan dalam rangka kegotong royongan nasional sebagai peran serta aktif masyarakat dalam membiayai pembangunan. Dalam Undang-Undang Ketentuan Umum Perpajakan No 28 Tahun 2007 (KUP), bahwa pajak adalah kontribusi wajib pajak kepada negara yang terutang oleh orang pribadi atau badan yang bersifat memaksa berdasarkan undang-undang dengan tidak mendapatkan imbalan secara langsung dan digunakan untuk keperluan negara bagi sebesar-besarnya kemakmuran rakyat. Indonesia termasuk negara yang berkembang, yang memiliki pendapatan dari berbagai sumber salah satunya yaitu berasal dari pemungutan pajak, baik pajak negara maupun pajak daerah yang menjadi sumber terbesar pendapatan negara kita berasal dari penerimaan pajak.

Kedua pajak ini merupakan sektor potensial, sehingga dengan adanya potensi tersebut diharapkan peningkatan realisasi dalam penerimaan pajak reklame, pajak bumi dan bangunan, yang diberikan oleh kedua pajak ini dapat memacu pembangunan ekonomi di Kabupaten Siau Tagulandang Biaro (SITARO) khususnya dan Sulawesi Utara pada umumnya. Dengan kedua pajak ini, pemerintah juga diharapkan dapat memantau setiap penerimaan pajak reklame, pajak bumi dan bangunan apakah berjalan efektif atau tidak efektif dan juga apakah memberikan kontribusi terhadap pemerintah daerah atau tidak. Karena dari pendapatan pajak inilah pemerintah daerah dapat melakukan pembenahan dan 
pembangunan fasilitas umum yang telah direncanakan atau mau dijalankan oleh pemerintah daerah Kabupaten Siau Tagulandang Biaro (SITARO).

\section{TINJAUAN PUSTAKA}

\subsection{Akuntansi Perpajakan}

Pajak adalah iuran masyarakat kepada negara (yang dapat dipaksakan) yang terutang oleh yang wajib membayarnya menurut peraturan-peraturan umum (undang-undang) dengan tidak mendapat prestasi kembali yang langsung dapat ditunjuk dan yang gunanya untuk membiayai pengeluaran-pengeluaran umum berhubung tugas negara untuk menyelenggarakan pemerintahan (Diana Sari 2013:34). Menurut Resmi (2014:1), pajak adalah iuran rakyat kepada kas negara berdasarkan undang-undang (yang dapat dipaksakan) dengan tidak mendapat jasa timbal balik (kontrasepsi) yang langsung dapat ditunjukan dan yang digunakan untuk membayar pengeluaran umum.

Menurut Waluyo (2013:3), pajak adalah iuran wajib berupa uang atau barang yang dipungut oleh penguasa berdasarkan norma-norma hukum, guna menutup biaya produksi barang-barang dan jasa-jasa kolektif dalam mencapai kesejahteraan umum. Pajak adalah pembayaran yang bersifat paksaan kepada negara yang dibebankan pada pendapatan kekayaan seseorang yang diutamakan untuk membiayai pengeluaran negara (Diana Sari 2013:35).

Dalam menetapkan besarnya pajak terutang tetap mendasarkan laporan keuangan yang disusun oleh perusahaan, mengingat dalam ketentuan perundang-undangan perpajakan terdapat aturan-aturan khusus yang berkaitan dengan akuntansi, yaitu masalah konsep transaksi dan peristiwa keuangan,metode pengukurannya serta pelaporannya yang ditetapkan dengan undang-undang (Waluyo, 2012:35).

\subsection{Pendapatan Asli Daerah (PAD)}

Pendapatan Asli Daerah Pendapatan Daerah adalah semua hak daerah yang diakui sebagai penambah nilai kekayaan bersih dalam periode anggaran tertentu (UU No 32 Tahun 2004 tentang Pemerintahan Daerah), Pendapatan Daerah berasal dari penerima lain-lain pendapatan yang sah. Adapun sumber-sumber Pendapatan Asli Daerah menurut UndangUndang RI No.32 Tahun 2004 yaitu:

1. Pendapatan Asli Daerah (PAD) yang terdiri dari:

a.Hasil Pajak Daerah yaitu Pungutan daerah menurut peraturan yang ditetapkan oleh daerah untuk pembiayaan rumah tangganya sebagai badan hukum publik. Pajak Daerah sebagai pungutan yang dilakukan Pemerintah Daerah yang hasilnya digunakan untuk pengeluaran umum yang balas jasanya tidak langsung diberikan sedang pelaksanaannya bisa dapat dipaksakan.

b.Hasil Retribusi Daerah yaitu pungutan yang telah secara sah menjadi pungutan daerah sebagai pembayaran pemakaian atau karena memperoleh jasa atau karena memperoleh jasa pekerjaan, usaha atau milik Pemerintah Daerah bersangkutan. Retribusi Daerah mempunyai sifat-sifat yaitu pelaksanaannya bersifat ekonomis, ada imbalan langsung walau harus memenuhi persyaratan-persyaratan formil dan materil, tetapi ada alternatif untuk mau tidak membayar, merupakan pungutan yang sifatnya budgetairnya tidak menonjol, dalam hal-hal tertentu Retribusi Daerah adalah pengembalian biaya yang telah dikeluarkan oleh Pemerintah Daerah untuk memenuhi permintaan anggota masyarakat.

c.Hasil perusahaan milik daerah dan hasil pengelolaan kekayaan daerah yang dipisahkan. Hasil perusahaan milik daerah merupakan Pendapatan Daerah dari keuntungan bersih perusahaan daerah yang berupa dana pembangunan daerah dan bagian untuk anggaran belanja daerah yang disetor ke kas daerah, baik perusahaan daerah yang dipisahkan, sesuai dengan motif pendirian dan pengelolaan, maka sifat perusahaan daerah adalah 
suatu kesatuan produksi yang bersifat menambah Pendapatan Daerah, memberi jasa, menyelenggarakan kemanfaatan umum, dan memperkembangkan perekonomian daerah.

d.Lain-lain Pendapatan Daerah yang sah ialah pendapatan-pendapatan yang tidak termasuk dalam jenis-jenis Pajak Daerah, Retribusi Daerah, Pendapatan dinas-dinas. Lain-lain usaha daerah yang sah mempunyai sifat yang pembuka bagi Pemerintah Daerah untuk melakukan kegiatan yang menghasilkan baik berupa materi dalam kegiatan tersebut bertujuan untuk menunjang, melapangkan, atau memantapkan suatu kebijakan daerah disuatu bidang tertentu.

2.Dana Perimbangan diperoleh melalui bagian Pendapatan Daerah dari penerimaan Pajak Bumi dan Bangunan Pertambangan sumber daya alam dan serta bea perolehan hak atas tanah dan bangunan. Dana Perimbangan terdiri atas dana bagi hasil, dana alokasi umum, dan dana alokasi khusus.

3.Lain-lain Pendapatan Daerah yang sah adalah Pendapatan Daerah dari sumber lain misalnya sumbangan pihak ketiga kepada daerah yang dilaksanakan sesuai dengan peraturan perundangan-undangan yang berlaku.

\subsection{Pajak Daerah}

Pajak daerah merupakan pajak yang ditetapkan oleh pemerintah daerah dengan peraturan daerah (perda), yang wewenang pungutannya dilaksanakan oleh pemerintah daerah dan hasilnya digunakan untuk membiayai pengeluaran pemerintah daerah dalam melaksanakan penyelenggaraan pemerintah dan pembangunan di daerah (Siahaan 2013:9).

\subsubsection{Kriteria Pajak Daerah}

Menurut Departemen Keuangan Republik Indonesia Direktorat Jenderal Perimbangan Keuangan tentang Pajak Daerah dan Retribusi Daerah, yang merupakan kriteria Pajak Daerah antara lain sebagai berikut :

1. Bersifat pajak bukan Retribusi.

2. Objek pajak terletak atau terdapat diwilayah daerah kabupaten/kota yang bersangkutan dan mempunyai mobilitas cukup rendah serta hanya melayani masyarakat di wilayah daerah kabupaten/kota yang bersangkutan.

3. Objek dan dasar pengenaan pajak tidak bertentangan dengan kepentingan umum.

4. Potensinya memadai. Hasil penerimaan pajak harus lebih besar dari biaya pemungutan.

5. Tidak memberikan dampak ekonomi yang negatif. Pajak tidak mengganggu alokasi sumber-sumber ekonomi dan tidak merintangi arus sumber daya ekonomi antar daerah maupun kegiatan eksport-impor.

6. Memperhatikan aspek keadilan dan kemampuan masyarakat.

7. Menjaga kelestarian lingkungan, yang berarti bahwa pengenaan pajak tidak memberikan peluang kepada pemerintah atau masyarakat luas untuk merusak lingkungan.

\subsection{Sistem Pemungutan Pajak Daerah}

Menurut Mardiasmo (2011:15) pemungutan pajak daerah dilarang diborongkan. Setiap Wajib Pajak wajib membayar pajak yang terutang berdasarkan surat ketetapan pajak atau pajak dibayar sendiri oleh wajib pajak berdasarkan peraturan perundang-undangan perpajakan. Wajib pajak yang memenuhi kewajiban perpajakan berdasarkan penetapan Kepala Daerah dibayar dengan menggunakann Surat Ketetapan Pajak Daerah (SKPD) atau dokumen lain yang dipersamakan berupa karcis atau nota perhitungan. Terdapat beberapa sistem pemungutan pajak daerah yang berlaku dewasa ini. Sistem pemungutan pajak daerah itu diantaranya ialah dengan sistem setor tunai, sistem pembayaran dimuka, sistem pengaitan, sistem benda berharaga dan sistem kartu. 


\subsection{Pajak Reklame}

Menurut Azhari Samudra (2016:216) Pajak Reklame adalah pajak atas penyelenggaraan reklame. Sedangkan yang dimaksud dengan reklame adalah benda, alat, perbuatan atau media yang bentuk corak ragamnya dirancang untuk tujuan komersial memperkenalkan, menganjurkan, mempromosikan, atau untuk menarik perhatian umum terhadap barang, jasa, orang, atau badan yang dapat dilihat, dibaca, didengar, dirasakan, dan/atau dinikmati oleh umum.

Beberapa pengertian yang perlu untuk dijelaskan agar lebih memudahkan bahasa selanjutnya adalah sebagai berikut :

1. Reklame, ialah benda, alat atau perbuatan, yang menurut bentuk susunan atau corak ragamnya dengan maksud untuk mencari keuntungan (sales promotion) dipergunakan untuk memperkenalkan, menganjurkan atau memujikan suatu barang, jasa seseorang ataupun untuk menarik perhatian umum kepada suatu barang, jasa atau seseorang yang ditempatkan atau yang dapat dilihat, dibaca dan didengar dari sesuatu tempat oleh umum, kecuali yang dilakukan oleh pemerintah.

2. Izin ialah izin penyelenggara reklame yang terdiri dari izin tetap dan izin terbatas. Reklame tetap ialah reklame yang izinya berlaku sampai ada pencabutan. Reklame tidak tetap ialah reklame yang jangka waktu berlakunya ditetapkan dalam izin.

3. Nilai sewa reklame ialah nilai yang ditetapkan sebagai dasar perhitungan penetapan besarnya reklame.

4. Titik reklame adalah tempat di mana bidang reklame didirikan atau ditempelkan baik di dalam prasarana dan sarana kota atau diluarnya.

5. Surat permohonan penyelenggaraan reklame (SPPR) ialah surat yang digunakan oleh yang mengajukan permohonan penyelenggara reklame dan mendaftarkan identitas pemilik reklame sebagai dasar perhitungan pajak terutang.

6. Surat izin bekerja perencana (SIBP) ialah surat izin yang diberikan kepada seorang ahli untuk dapat melakukan pekerjaan sebagai peneliti tanah, perancang, pengawas, pengkaji teknis dan pemelihara bangunan di Provinsi Jakarta sesuai dengan keahliannya.

7. Surat kuasa untuk menyetor (SKUM) adalah nota untuk perhitungan besarnya pajak reklame yang harus dibayar oleh wajib pajak yang berfungsi sebagai ketetapan pajak.

\subsection{Pajak Bumi dan Bangunan}

Pajak Bumi dan Bangunan adalah pajak yang bersifat kebendaan, dalam arti besarnya pajak terutang ditentukan oleh keadaan objek pajak yaitu bumi dan bangunan. Keadaan subjek (siapa yang membayar) tidak ikut menentukan besarnya jumlah pajak yang terutang (Mardiasmo 2013:331).

Bumi adalah permukaan bumi dan tubuh bumi yang ada dibawahnya. Permukaan bumi meliputi tanah dan perairan pedalaman (termasuk rawa-rawa, tambak, perairan) serta laut wilayah Republik Indonesia. Bangunan adalah konstruksi teknik yang ditanam atau dilekatkan secara tetap pada tanah dan atau perairan.

Termasuk dalam pengertian bangunan adalah ;

a. Jalan lingkungan dalam satu kesatuan dengan kompleks bangunan.

b. Jalan tol.

c. Kolam renang.

d. Pagar mewah.

e. Tempat olah raga.

f. Galangan kapal, dermaga.

g. Taman mewah.

h. Tempat pembangunan/kilang minyak, air dan gas, pipa minyak.

i. Fasilitas lain yang memberikan manfaat. 


\subsection{Efektivitas}

Mahmudi (2010:143) menyatakan bahwa efektivitas merupakan hubungan antara keluaran dengan tujuan atau sasaran yang harus dicapai. Efektivitas juga berarti pemanfaatan sumber daya, saran prasarana dalam jumlah tertentu yang secara sadar ditetapkan sebelumnya untuk mengahsilkan sejumlah barang atas jasa kegiatan yang dijalankannya. Efektivitas menunjukan keberhasilan dari segi tercapai tidaknya sasaran yang telah ditetapkan. Jika hasil kegiatan semakin mendekati sasaran, berarti makin tinggi efektivitasnya.dapat disimpulkan bahwa efektivitas berkaitan dengan terlaksananya semua tugas pokok, tercapainya tujuan, ketetapan waktu dan partisipasi aktif dari anggota serta merupakan keterkaitan antara tujuan dan hasil yang dinyatakan, dan menunjukan derajat kesesuaian antara tujuan yang dinyatakan dengan hasil yang dicapai.Dikatakan efektif apabila proses kegiatan mencapai tujuan dan sasaran akhir kebijakan (spending wisley). Untuk menganalisis tingkat efektivitas dari pajak reklame, dan pajak bumi dan bangunan maka peneliti menggunakan rumus :

$$
\text { Efektivitas }=\frac{\text { Realisasi Penerimaan Pajak }}{\text { Target Penerimaan Pajak }} \times 100 \%
$$

\subsection{Kontribusi}

Kontribusi digunakan untuk mengetahui sejauh mana pajak daerah memberikan sumbangan dalam penerimaan PAD. Dalam mengetahui kontribusi dilakukan dengan membandingkan Penerimaan Pajak Daerah (PAD) periode tertentu pula. Semakin besar hasilnya berarti semakin besar hasilnya berarti semakin besar pula peranan pajak daerah terhadap Pendapat Asli Daerah, begitu pula sebaliknya jika hasil perbandingannya terlalu kecil berarti peranan pajak daerah terhadap Pendapatan Asli Daerah juga kecil (Mahmudi, 2010:145).

Kontribusi positif adalah kontribusi tersebut membuat sebuah kemajuan, bukan menurunkan ataupun membuat gagal suatu tujuan. Bedasarkan pengertian kontribusi yang dikemukakan diatas maka dapat diartikan bahwa kontribusi penerimaan pajak daerah sangat penting untuk mengembangkan kemajuan daerah. Dalam mengetahui Kontribusi dilakukan dengan membandingkan penerimaan pajak daerah. Untuk mengetahui besar kontribusi pajak reklame, dan pajak bumi bangunan terhadap pendapatan asli daerah Kabupaten Siau Tagulandang Biaro, digunakan Rumus :

$$
\text { Kontribusi }=\frac{\text { Realisasi Penerimaan Pajak }}{\text { Target Penerimaan PAD }} \times 100 \%
$$

\subsection{Penelitian Terdahulu}

1. Penelitian yang dilakukan Rima Adelia (2013) bahwa Dinas Pendapatan, Pengelolaan Keuangan dan Aset Daerah Kabupaten Gresik telah berhasil dalam merealisasikan Pajak Bumi dan Bangunan atau lebih dari target Pajak Bumi dan Bangunan yang telah ditentukan

2. Penelitian yang dilakukan Eliya Isfaatun (2014) Upaya yang dilakukan oleh Dinas Pendapatan Daerah Kabupaten Sleman dalam menghimpun penerimaan pajak daerah sudah efektif

3. Penelitian yang dilakukan Ratna Juwita (2012) menggambarkan Prosedur Penerimaan Pajak Bumi dan Bangunan (PBB) setelah dialihkan dari Pajak Pusat menjadi Pajak Daerah sudah berjalan dengan baik dan tergolong sudah cukup efektif. 


\section{METODE PENELITIAN}

\subsection{Jenis dan Sumber Data}

Jenis penelitian yang digunakan penulis adalah penelitian deskriptif kuantitatif, yang dilakukan dengan cara mengumpulkan data yang berhubungan dengan permasalahan yang dihadapi. Data merupakan keterangan-keterangan yang diperoleh dari penelitian atau melalui referensi-referensi yang ada untuk menganalisis efektifitas dan kontribusi pemungutan pajak reklame, pajak bumi dan ban gunan terhadap pendapatan asli daerah Kabupaten Siau Tagulandang Biaro. Metode pengumpulan data dalam penelitian ini adalah:

1. Menunjukan surat penelitian dari Fakultas Ekonomi dan Bisnis sebagai bukti untuk pengambilan data kepada pihak Badan Keuangan Kabupaten Siau Tagulandang Biaro.

2. Wawancara, melakukan diskusi dan tanya jawab secara langsung dengan pihak-pihak yang berkompoten untuk memberikan keterangan mengenai pajak reklame, pajak bumi dan bangunan serta kendala-kendala dalam proses pemungutan pajak.

3. Dokumentasi, serta bahan-bahan dari instansi yang berhubungan dengan penelitian ini, misalnya struktur organisasi, Data Pendapatan Asli Daerah (PAD), sejarah Kabupaten serta tugas dan kerja dari instansi Badan Keuangan Kabupaten Siau Tagulandang Biaro

\subsection{Metode Analisis Data}

Metode analisis data yang digunakan dalam penelitian ini adalah menggunakan metode analisis deskriptif. Analisis deskriptif adalah analisis yang diwujudkan dengan cara menggambarkan kenyataan atau keadaan-keadaan atas suatu objek dalam bentuk uraian kalimat, data angka berdasarkan keterangan-keterangan dari pihak-pihak yang berhubungan langsung dengan penelitian ini. Hasil analisis tersebut kemudian diinterpretasikan guna memberikan gambaran yang jelas terhadap permasalahan yang diajukan.

\section{HASIL ANALISIS DAN PEMBAHASAN}

\subsection{Hasil Analisis}

\subsubsection{Realisasi Penerimaan Pajak Reklame, Pajak Bumi dan Bangunan Kabupaten Siau} Tagulandang Biaro

Hasil Penelitian yang diperoleh dari Badan Keuangan Kabupaten Siau Tagulandang Biaro yaitu target dan realisasi Pajak Reklame, Pajak Bumi dan Bangunan sedangkan untuk perhitungan efektivitas dan kontribusi tidak terdapat data pada pemerintah daerah, sehingga perhitungan dilakukan sendiri oleh penulis.

\section{Tabel 4.1}

Target dan Realisasi Penerimaan Pajak Reklame Kabupaten Siau Tagulandang Biaro Tahun 2014-2016

\begin{tabular}{|l|l|l|l|}
\hline No & Tahun & $\begin{array}{c}\text { Target Pajak Reklame } \\
(\mathrm{RP})\end{array}$ & $\begin{array}{c}\text { Realisasi Pajak Reklame } \\
(\mathrm{Rp})\end{array}$ \\
\hline 1 & 2014 & $\mathrm{Rp} 118.344 .000$ & $\mathrm{Rp} 122.026 .813$ \\
\hline 2 & 2015 & $\mathrm{Rp} 162.325 .000$ & $\mathrm{Rp} 164.155 .259$ \\
\hline 3 & 2016 & $\mathrm{Rp} 160.965 .007$ & $\mathrm{Rp} 163.131 .090$ \\
\hline
\end{tabular}

Sumber data:Bidang Pendapatan Kabupaten SITARO 


\section{Tabel 4.2}

Target dan Realisasi Penerimaan Pajak Bumi dan Bangunan Kabupaten Siau Tagulandang Biaro Tahun 2015-2016

\begin{tabular}{|l|l|c|c|}
\hline No & Tahun & $\begin{array}{c}\text { Target Pajak Bumi } \\
\text { Bangunan (Rp) }\end{array}$ & $\begin{array}{l}\text { Realisasi pajak Bumi } \\
\text { Bangunan (Rp) }\end{array}$ \\
\hline 1 & 2014 & - & - \\
\hline 2 & 2015 & $\operatorname{Rp} 701.652 .432$ & $\operatorname{Rp} 691.489 .178$ \\
\hline 3 & 2016 & $\mathrm{Rp} 709.950 .987$ & $\mathrm{Rp} 694.812 .270$ \\
\hline
\end{tabular}

Sumber data:Bidang Pendapatan Kabupaten SITARO

\subsubsection{Realisasi Penerimaan PAD, Realisasi penerimaan Pajak Reklame, Pajak bumi dan Bangunan Kabupaten Siau Tagulandang Biaro}

Tabel 4.3

Realisasi Penerimaan PAD dan Realisasi Penerimaan Pajak Reklame, Kabupaten SITARO 2014-2016

\begin{tabular}{|l|l|l|l|}
\hline No & Tahun & $\begin{array}{l}\text { Realisasi Pajak Reklame } \\
(\mathrm{Rp})\end{array}$ & $\begin{array}{l}\text { Realisasi PAD Kabupaten } \\
\text { SITARO (Rp) }\end{array}$ \\
\hline 1 & 2014 & $\mathrm{Rp} \mathrm{122.026.813}$ & $\mathrm{Rp} \mathrm{20.681.159.632}$ \\
\hline 2 & 2015 & $\mathrm{Rp} \mathrm{164.155.259}$ & $\mathrm{Rp} \mathrm{20.818.151.553}$ \\
\hline 3 & 2016 & $\mathrm{Rp} \mathrm{163.131.090}$ & $\mathrm{Rp} \mathrm{19.371.962.089}$ \\
\hline
\end{tabular}

Sumber data:Bidang Pendapatan Kabupaten SITARO

Tabel 4.4

Realisasi Penerimaan PAD dan Realisasi Penerimaan Pajak Bumi dan Bangunan Kabupaten SITARO 2015-2016

\begin{tabular}{|l|l|l|l|}
\hline No & Tahun & $\begin{array}{l}\text { Realisasi Pajak Bumi dan } \\
\text { Bangunan (Rp) }\end{array}$ & $\begin{array}{l}\text { Realisasi PAD Kabupaten } \\
\text { SITARO (Rp) }\end{array}$ \\
\hline 1 & 2015 & $\operatorname{Rp} 691.489 .178$ & Rp 20.818.151.553 \\
\hline 2 & 2016 & $\operatorname{Rp} 694.812 .270$ & $\operatorname{Rp~19.371.962.089~}$ \\
\hline
\end{tabular}

Sumber data:Bidang Pendapatan Kabupaten SITARO

\subsection{Pembahasan}

\subsubsection{Efektifitas Pemungutan Pajak Reklame, Pajak Bumi dan Bangunan}

1. Efektivitas Pajak Reklame

Pajak Reklame merupakan bagian dalam Pajak Daerah yang adalah sumber penerimaan utama dalam Penerimaan Asli Daerah. Berikut ini adalah tabel target dan realisasi Pajak Reklame Kabupaten SITARO tahun2014-2016.

\section{Tabel 4.5}

Target dan Realisasi Pajak Reklame Kabupaten Siau Tagulandang Biaro

\begin{tabular}{|l|l|l|l|l|}
\hline Tahun & $\begin{array}{l}\text { Target Pajak } \\
\text { Reklame (Rp) }\end{array}$ & $\begin{array}{l}\text { Realisasi Pajak } \\
\text { Reklame (Rp) }\end{array}$ & Presentase & Kriteria \\
\hline 2014 & $\mathrm{Rp} \mathrm{118.344.000}$ & $\mathrm{Rp} \mathrm{122.026.813}$ & $103,11 \%$ & Sangat Efektif \\
\hline 2015 & $\mathrm{Rp} \mathrm{162.325.000}$ & $\mathrm{Rp} \mathrm{164.155.269}$ & $101,12 \%$ & Sangat Efektif \\
\hline 2016 & $\mathrm{Rp} \mathrm{160.965.007}$ & $\mathrm{Rp} \mathrm{163.131.090}$ & $101,34 \%$ & Sangat Efektif \\
\hline
\end{tabular}

Sumber data:Bidang Pendapatan Kabupaten SITARO 
Menurut data yang ada maka dapat di hitung tingkat efektifitas Pajak Reklame menggunakan rumus :

$$
\text { Efektivitas }=\frac{\text { Realisasi Penerimaan Pajak }}{\text { Target Penerimaan Pajak }} \times 100 \%
$$

Pajak Reklame :

1.Tahun 2014 :

Efektivitas $=\frac{122.026 .813}{118.344 .000} \times 100 \%$

$$
=103,11 \%
$$

2.Tahun 2015

$$
\begin{aligned}
\text { Efektivitas } & =\frac{164.155 .259}{162.325 .000} \times 100 \% \\
& =101,12 \%
\end{aligned}
$$

3.Tahun 2016

$$
\begin{aligned}
\text { Efektivitas } & =\frac{163.131 .090}{160.965 .007} \times 100 \% \\
& =101,34 \%
\end{aligned}
$$

Perhitungan efektivitas berdasarkan target dilakukan dengan cara membandingkan realisasi pemungutan Pajak Reklame dengan target Pemungutan Pajak Reklame. Berdasarkan tabel diatas, perhitungan efektivitas Pajak Reklame tahun 2014 sampai dengan tahun 2016 menunjukan angka yang sangat efektif yaitu melebihi 100\%. Yaitu pada tahun 2014 presentase mencapai $103,11 \%$ dengan kategori sangat efektif, pada tahun 2015 presentase mencapai 101,12\% dengan kategori sangat efektif dan untuk tahun 2016 presentase mencapai $101,34 \%$ dengan kategori sangat efektif. Sehingga dapat disimpulkan bahwa dari tahun 2014 sampai dengan tahun 2016 pemungutan Pajak Reklame dinilai sangat efektif. Untuk rata-rata efektivitas Pajak Reklame yaitu sebesar $101,85 \%$ yang menurut kriteria berarti sangat efektif.

Berdasarkan hasil analisis efektivitas penerimaan Pajak Reklame dapat disimpulkan bahwa Badan Keuangan Daerah Kabupaten Siau Tagulandang Biaro telah berhasil dalam merealisasikan Pajak Reklame atau lebih dari target Pajak Reklame yang telah ditentukan. Untuk itu pemerintah dalam hal ini Badan Keuangan Daerah Kabupaten Siau Tagulandang Biaro harus tetap berusaha mempertahankan efektifitas pemungutan Pajak Reklame.

2. Efektivitas Pajak Bumi dan Bangunan

Pajak Bumi dan Bangunan merupakan bagian dalam Pajak Daerah yang adalah sumber penerimaan utama dalam Penerimaan Asli Daerah. Berikut ini adalah tabel target dan realisasi Pajak Bumi dan Bangunan Kabupaten SITARO tahun 2015-2016. 
Tabel 4.6

Target dan Realisasi Pajak Bumi dan Bangunan Kabupaten Siau Tagulandang Biaro

\begin{tabular}{|l|c|l|c|c|}
\hline Tahun & $\begin{array}{l}\text { Target Pajak Bumi } \\
\text { dan Bangunan (Rp) }\end{array}$ & $\begin{array}{l}\text { Realisasi Pajak } \\
\text { Bumi Presentase } \\
\text { Bangunan (Rp) }\end{array}$ & Kriteria \\
\hline 2014 & - & - & - & - \\
\hline 2015 & Rp 701.652.432 & Rp 691.489.178 & $98,55 \%$ & Efektif \\
\hline 2016 & Rp 709.950.987 & Rp 694.812.270 & $97,86 \%$ & Efektif \\
\hline
\end{tabular}

Sumber data:Bidang Pendapatan Kabupaten SITARO

Menurut data yang ada maka dapat di hitung tingkat efektifitas Pajak Bumi dan Bangunan menggunakan rumus :

$$
\text { Efektivitas }=\frac{\text { Realisasi Penerimaan Pajak }}{\text { Target Penerimaan Pajak }} \times 100 \%
$$

Pajak Bumi Bangunan :

1.Tahun 2015

$$
\begin{aligned}
\text { Efektivitas } & =\frac{691.489 .178}{701.652 .432} \times 100 \% \\
& =98,55 \%
\end{aligned}
$$

2.Tahun 2016

$$
\begin{aligned}
\text { Efektivitas } & =\frac{694.812 .270}{709.950 .987} \times 100 \% \\
& =97,86 \%
\end{aligned}
$$

Perhitungan efektivitas berdasarkan target dilakukan dengan cara membandingkan realisasi pemungutan Pajak Bumi dan Bangunan dengan target Pemungutan Pajak Bumi dan Bangunan. Berdasarkan tabel diatas, perhitungan efektivitas Pajak Bumi dan Bangunan tahun 2015 sampai dengan tahun 2016 belum mencapai target yang telah ditetapkan namun kriteria efektivitas menunjukan angka yang efektif yaitu melebihi 90\%. Yaitu pada tahun 2015 presentase mencapai 98,55\% dengan kategori efektif, dan pada tahun 2016 presentase mencapai 97,86\% dengan kategori efektif. Sehingga dapat disimpulkan bahwa dari tahun 2015 sampai dengan tahun 2016 pemungutan Pajak Reklame dinilai efektif. Untuk rata-rata efektivitas Pajak Reklame yaitu sebesar 98,20\% yang menurut kriteria berarti efektif.

\subsubsection{Kontribusi Pajak Reklame, Pajak Bumi dan Bangunan}

\section{Kontribusi Pajak Reklame}

Analisis kontribusi yaitu perbandingan antara hasil realisasi penerimaan tahun berjalan atas Pajak Reklame dengan jumlah realisasi Pendapatan Asli Daerah. Analisis kontribusi merupakan analisis untuk mengetahui seberapa besar kontribusi pajak reklame, sebagai sumber Pendapatan Asli Daerah. Semakin tinggi kontribusi pajak daerah dalam hal ini pajak reklame, maka semakin tinggi pula kemampuan daerah untuk membiayai pemerintahannya sendiri. Kemampuan pembiayaan itu menunjukan adanya kinerja keuangan yang positif yaitu kemandirian dalam membiayai kebutuhan daerah. Berikut ini adalah tabel target dan realisasi Pendapatan Asli Daerah Kabupaten Siau Tagulandang Biaro tahun 2014-2016. 


\section{Tabel 4.7}

Kontribusi Pajak Reklame Terhadap Pendapatan Asli Daerah Kabupaten Siau Tagulandang Biaro Tahun 2014-2016

\begin{tabular}{|l|l|l|l|l|}
\hline Tahun & $\begin{array}{l}\text { Realisasi Pajak } \\
\text { Reklame (Rp) }\end{array}$ & $\begin{array}{l}\text { Pendapatan Asli } \\
\text { Daerah (PAD) (Rp) }\end{array}$ & $\begin{array}{l}\text { Presentase } \\
\text { Kontribusi } \\
(\%)\end{array}$ & Kriteria \\
\hline 2014 & Rp 122.026.813 & Rp 20.681.159.622 & $0,59 \%$ & $\begin{array}{l}\text { Sangat } \\
\text { Kurang }\end{array}$ \\
\hline 2015 & Rp 164.155.259 & Rp 20.818.151.553 & $0,78 \%$ & $\begin{array}{l}\text { Sangat } \\
\text { Kurang }\end{array}$ \\
\hline 2016 & Rp 163.131.090 & Rp 19.371.962.089 & $0,84 \%$ & $\begin{array}{l}\text { Sangat } \\
\text { Kurang }\end{array}$ \\
\hline
\end{tabular}

\section{Sumber data:Bidang Pendapatan Kabupaten SITARO}

Menurut data yang ada maka dapat dihitung kontribusi pajak reklame terhadap PAD Kabupaten SITARO menggunakan rumus :

$$
\text { Kontribusi }=\frac{\text { Realisasi Penerimaan Pajak }}{\text { Target Penerimaan PAD }} \times 100 \%
$$

Pajak Reklame :

1.Tahun 2014

Kontribusi $=\frac{122.026 .813}{20.681 .159 .632} \times 100 \%$

$$
=0.59 \%
$$

2.Tahun 2015

$$
\begin{aligned}
\text { Kontribusi } & =\frac{164.155 .259}{20.818 .151 .553} \times 100 \% \\
& =0.78 \%
\end{aligned}
$$

3.Tahun 2016

$$
\begin{aligned}
\text { Kontribusi } & =\frac{163.131 .090}{19.371 .962 .089} \times 100 \% \\
& =0.84 \%
\end{aligned}
$$

Perhitungan analisis kontribusi Pajak Reklame terhadap Pendapatan Daerah menunjukan angka yang sangat kurang. Pada tahun 2014 kontribusi sebesar 0,59\% dengan kriteria sangat kurang, pada tahun 2015 mencapai 0,78\% dengan kriteria sangat kurang dan pada tahun 2016 kontribusi sebesar 0,84\% dengan kategori sangat kurang. Berdasarkan analisis Kontribusi Pajak Reklame dapat disimpulkan bahwa Pajak Reklame sebagai sumber Pendapatan Asli Daerah dinilai tidak maksimal dan masuk dalam kriteria sangat kurang. Hasil analisis diperoleh tingkat kontribusi rata-rata hanya $0,73 \%$ yang menurut kriteria sangat kurang atau rendah.

2. Kontribusi Pajak Bumi dan bangunan

Analisis kontribusi yaitu perbandingan antara hasil realisasi penerimaan tahun berjalan atas Pajak Bumi dan Bangunan dengan jumlah realisasi Pendapatan Asli Daerah. 
Analisis kontribusi merupakan analisis untuk mengetahui seberapa besar kontribusi pajak bumi dan bangunan, sebagai sumber Pendapatan Asli Daerah. Semakin tinggi kontribusi pajak daerah dalam hal ini Pajak Bumi dan Bangunan, maka semakin tinggi pula kemampuan daerah untuk membiayai pemerintahannya sendiri. Kemampuan pembiayaan itu menunjukan adanya kinerja keuangan yang positif yaitu kemandirian dalam membiayai kebutuhan daerah. Berikut ini adalah tabel target dan realisasi Pendapatan Asli Daerah Kabupaten Siau Tagulandang Biaro tahun 2014-2016.

Tabel 4.8

Kontribusi Pajak Bumi dan Bangunan Terhadap Pendapatan Asli Daerah Kabupaten Siau Tagulandang Biaro 2015-2016

\begin{tabular}{|c|c|c|c|c|}
\hline Tahun & $\begin{array}{c}\text { Realisasi Pajak } \\
\text { Bumi dan } \\
\text { Bangunan (Rp) }\end{array}$ & $\begin{array}{c}\text { Pendapatan Asli } \\
\text { Daerah (PAD) }\end{array}$ & $\begin{array}{c}\text { Presentase } \\
\text { Kontribusi } \\
(\%)\end{array}$ & Kriteria \\
\hline 2014 & - & - & - & - \\
\hline 2015 & Rp 691.489.178 & Rp 20.818.151.553 & $3,32 \%$ & $\begin{array}{l}\text { Sangat } \\
\text { Kurang }\end{array}$ \\
\hline 2016 & Rp 694.812.270 & Rp 19.371.962.089 & $3,58 \%$ & $\begin{array}{l}\text { Sangat } \\
\text { Kurang }\end{array}$ \\
\hline
\end{tabular}

Sumber data:Bidang Pendapatan Kabupaten SITARO

Menurut data yang ada maka dapat dihitung kontribusi pajak reklame terhadap PAD Kabupaten SITARO menggunakan rumus :

$$
\text { Kontribusi }=\frac{\text { Realisasi Penerimaan Pajak }}{\text { Target Penerimaan PAD }} \times 100 \%
$$

Pajak Bumi dan Bangunan :

1.Tahun 2015

$$
\begin{aligned}
\text { Kontribusi } & =\frac{691.489 .178}{20.818 .151 .553} \times 100 \% \\
& =3,32 \%
\end{aligned}
$$

2. Tahun 2016

$$
\begin{aligned}
\text { Kontribusi } & =\frac{694.812 .270}{19.371 .962 .089} \times 100 \% \\
& =3,58 \%
\end{aligned}
$$

Perhitungan analisis kontribusi Pajak Bumi dan Bangunan menunjukan angka yang sangat kurang yaitu kurang dari 10\%. Yakni pada tahun 2015 kontribusi sebesar 3,32\% dan pada tahun 2016 sebesar 3,58\%. Kontribusi Pajak Bumi Bangunan sebagai sumber Pendapatan Asli Daerah dinilai tidak maksimal dan masuk dalam kategori sangat kurang dengan hasil analisis kontribusi yang diperoleh rata-rata hanya 3,45\%.

\section{KESIMPULAN DAN SARAN}

\subsection{Kesimpulan}

Setelah dilakukan penelitian tentang Analisis Efektivitas dan Kontribusi Pemungutan Pajak Reklame, Pajak Bumi dan Bangunan Terhadap Pendapatan Asli Daerah Kabupaten Siau Tagulandang Biaro maka dapat diambil sebuah kesimpulan sebagai berikut : 
1. Tingkat efektifitas Pajak Reklame yang diterima oleh Badan Keuangan Daerah Kabupaten Siau Tagulandang Biaro Tahun 2014-2016 sangat efektif karena melebihi target yang telah ditetapkan.

2. Tingkat efektifitas Pajak Bumi dan Bangunan yang diterima oleh Badan Keuangan Daerah Kabupaten Siau Tagulandang Biaro Tahun 2015-2016 belum mencapai target yang telah ditetapkan, namun secara keseluruhan sudah efektif.

3. Jumlah penerimaan Pajak Reklame Kabupaten Siau Tagulandang Biaro Tahun 2014-2016 memberikan kontribusi terhadap Pendapatan Asli Daerah Kabupaten Siau Tagulandang Biaro namun dinilai tidak maksimal dan masuk dalam kriteria sangat kurang.

4. Jumlah penerimaan Pajak Bumi dan Bangunan Kabupaten Siau Tagulandang Biaro Tahun 2015-2016 memberikan kontribusi terhadap Pendapatan Asli Daerah Kabupaten Siau Tagulandang Biaro namun dinilai tidak maksimal dan masuk dalam kriteria sangat kurang

5. Realisasi Penerimaan Pendapatan Asli Daerah Kabupaten Siau Tagulandang Biaro pada tahun 2014 sebesar Rp 20.681.159.632, pada tahun 2015 sebesar 20.818.151.553 dan pada tahun 2016 Pendapatan Asli Daerah turun menjadi Rp 19.371.962.089.

\subsection{Saran}

Adapun saran yang dapat diberikan kepada Badan Keuangan Daerah Kabupaten Siau Tagulandang Biaro berhubungan dengan penelitian yang dilakukan adalah selalu berkomitmen pada target-target yang akan dicapai sehingga dapat memaksimalkan penerimaan pajak yang ada secara efektif, dan sebaiknya pemerintah meningkatkan fungsi kontrol dalam pemungutan pajak reklame, pajak bumi dan bangunan untuk meningkatkan kontribusi pajak terhadap Pendapatan Asli Daerah Kabupaten Siau Tagulandang Biaro. Dan peneliti berharap dengan adanya penelitian ini akan ada perubahan ke arah yang lebih baik.

\section{DAFTAR PUSTAKA}

Adelina, Rima. 2013. Analisis Efektifitas dan Kontribusi Penerimaan Pajak Bumi dan Bangunan (PBB) Terhadap Pendapatan Daerah di Kabupaten Gresik 20072011.Skripsi pada Universitas Negeri Surabaya.Gresik

Isfaatun, Eliya. 2014. Analisis Potensi, Efektifitas dan Kontribusi Pajak HotelTerhadap Penerimaan Pajak Daerah 2008-2012.Skripsi pada STIE Megar Kencana. Yogyakarta. ISSN-1411-3880.

Juwita, Ratna. 2012. Efektivitas Prosedur Penerimaan Pajak Bumi dan Bangunan (PBB) dari Pajak Pusat ke Pajak Daerah Pada Dinas Pendapatan Daerah Kota Palembang 20112012.Skripsi pada STIE MDP.Palembang

Mahmudi, 2010. Manajemen Keuangan Daerah, Penerbit Erlangga, Jakarta.

Mardiasmo, 2011. Perpajakan. Edisi Revisi 2011. Andi, Yogyakarta.

Mardiasmo. 2013. Perpajakan Edisi Revisi. Penerbit Andi, Yogyakarta

Resmi.Perpajakan Teori dan Kasus Edisi 7 Buku 1.Salemba Empat,Jakarta

Samudra, Azhari. 2016. Perpajakan di Indonesia:Keuangan,Pajak dan Retribusi Daerah.Rajawali Pers. Jakarta

Sari, Diana. 2013. Konsep Dasar Perpajakan.Refika Aditama, Bandung

Siahaan Marhiot P, 2013. Pajak Daerah dan Retribusi Daerah. Penerbit Rajawali Press. Jakarta.

Undang-undang Nomor 32 Tahun 2004 Tentang Pemerintahaan Daerah.

Undang-undang Nomor 28 Tahun 2007 Tentang Ketentuan Umum Perpajakan.

Waluyo. 2013. Akuntansi Perpajakan.Salemba Empat, Jakarta. 